\title{
Onnea 100-vuotiaalle politologialle!
}

\section{KATJA MÄKINEN MIIKA SALO}

Vuoden viimeisessä Politiikka-lehdessä tartutaan laajoihin eduskunta-aineistoihin käsitteellisellä otteella ja juhlitaan 100-vuotiasta suomalaista valtio-oppia. Ensimmäisessä artikkelissa "Määräysvalta vai mahdollisuus? Valta kansanedustajien muistitietohaastatteluissa" Matti Hyvärinen, Pauliina Latvala-Harvilahti ja Mykola Andrushchenko tarkastelevat politiikan tutkimuksen ydinkäsitettä, valtaa.

Artikkeli yhdistää käsitehistorian ja digitaalisen tiedonlouhinnan menetelmiä. Aineistona on liki 400 entisen kansanedustajan suomenkielistä haastattelua vuosilta 1988-2018. Eduskunnan kirjaston kokoama laaja aineistokokonaisuus on kansainvälisestikin ainutlaatuinen. Artikkelissa kysytään, miten itse politiikan toimijat eli veteraanikansanedustajat puhuvat vallasta. Huomio kohdistuu siihen, millainen poliittisen toiminnan ja merkityksenannon väline "valta" on.

Haastattelujen valtalausumat on poimittu koneellisesti tarkempaa laadullista analyysia ja tulkintaa varten. Aineiston käsittelyyn rakennetulla hakukoneella voidaan hakea sanatyyppien esiintymiä ja laskea erilaisia ominaisuuksia aineistosta. Tiedon louhinta mahdollistaa valtalausumien paikantamisen ja niiden yleisyyden arvioimisen.

Valtapuheen määrä vaihteli eri haastateltavien ja eri vuosien välillä. Vaikka haastateltavat ovat toimineet vallankäytön ammattilaisina, he eivät suullisen historian haastatteluissaan yleensä puhuneet vallasta oma-aloitteisesti, vaan vasta haastattelijan ottaessa asian esiin. Valtapuhetta kuitenkin löytyi lähes kaikista haastatteluista, mutta sen volyymi perustui paljolti haastattelijan valintoihin.

Valta näyttäytyy artikkelin perusteella monimerkityksellisenä ja moneen tarkoitukseen sopivana välineenä. Haastateltavien näkökannat jakautuivat siinä, miten kielteisenä, myönteisenä tai neutraalina ilmiönä he ymmärsivät vallan. Osa suhtautui valtaan kielteisenä tai enintään neutraalina ilmiönä. Valtaan torjuvasti suhtautuneet edustajat tulkitsivat vallan tyypillisesti toisten toimintaan kohdistuvana määräysvaltana ja komentovaltana (power-over). Toiset taas pitivät valtaa välttämättömänä, tarpeellisena ja hyväksyttävänä vaikkakaan ei ongelmattomana politiikan osana, joka mahdollistaa toimintaa (valta johonkin).

Monet poliitikot näkivätkin vallan mahdollisuutena, joka vaatii tilanteen lukutaitoa ja kykyä muuttaa tilannetta. He puhuivat yhteistyöhön pohjautuvasta vallasta, vaikutusvallasta ja arvovallasta. Käsitys vallasta dominointina tai hegemoniana puolestaan esiintyi haastatteluissa lähinnä silloin, kun veteraanikansanedustajat puhuivat sellaisesta vallasta, jota he halusivat vastustaa kuten talouden tai median ylivaltaa.

Kiinnostavaksi vallan käsitteen kontekstiksi artikkelissa nostetaan perustuslain muuttamisprosessi vuonna 2000 ja sitä edeltävä keskustelu presidentin valtaoikeuksien rajaamisesta. Tässä keskustelussa valta nähtiin vallan käyttäjän oikeutena määrätä muiden toiminnasta.

Myös toisessa tutkimusartikkelissa tarkastellaan laajaa eduskunta-aineistoa, ja myös siinä yhdistellään käsitehistorian lähestymistapoja ja ison datan tekstinlouhintaa. Artikkelissa 
"Luonnonsuojelusta ilmastopolitiikkaan. Ympäristöpoliittisen puhunnan muutos eduskuntakeskusteluissa 1960-2020” Kimmo Elo ja Jenni Karimäki tutkivat ympäristöä koskevaa keskustelua eduskunnan digitoitujen täysistuntopöytäkirjojen pohjalta. Laajaa aineistoa tutkitaan sekä laskennallisten yhteiskuntatieteiden tekstinlouhinnan ja eksploratiivisen data-analyysin että laadullisen tutkimuksen menetelmin. Digitaalisten ihmistieteiden avulla kirjoittajat tulkitsevat keskustelun ja siinä käytetyn käsitteistön muutoksia, pysyvyyttä ja politisointia.

Laadullista ja määrällistä tutkimusta yhdistävässä artikkelissa ympäristöä koskevien täysistuntopuheenvuorojen määriä ja sisältöjä tarkastellaan myös puolueittain, mikä tuo valoa siihen, miten ympäristökysymyksillä ja -käsitteillä politikoidaan. Analyysin mukaan ympäristöpuhe on valtavirtaistunut, ja nykyisin kaikkien eduskuntapuolueiden edustajat tuottavat sitä. Kaiken kaikkiaan ympäristöä koskevat keskustelut eduskunnan täysistunnoissa ovat artikkelin mukaan lisääntyneet tasaisesti, vaikka keskustelujen intensiteetti onkin vaihdellut.

Myös ympäristöä koskevien täysistuntokeskustelujen sisältö on muuttunut. Analyysi osoittaa, että ympäristötematiikasta puhuttaessa viitataan yhä yleisemmin yhteiskuntaan ja ihmisen toimintaan. Siirtymä kohti yhteiskunnallisten näkökulmien yleistymistä näkyy siinä, että keskusteluihin on noussut politiikkaa, arvoja, elämäntapoja ja kansainvälistä yhteistyötä koskeva muutos. Keskusteluissa nähtiin aikaisempaa vahvemmin, että ilmastonmuutoksen hillitsemiseksi tarvitaan tällaista laajempaa yhteiskunnallista ja kulttuurista muutosta, joka ei rajoitu luonnon tai ympäristön suojeluun.

Artikkelin pohjalta voidaan todeta, että ympäristöteemaan liittyvän eduskuntapuheen käsitteistö ja merkitykset ovat laajentuneet, ja ympäristö- ja ilmastopolitiikasta keskustellaan nykyisin yhteiskuntakehitystä kokonaisvaltaisesti ohjaavana toimintaraamina. Ilmastokysymysten nähtiin yleisesti koskettavan kaikkia politiikkasektoreita ja hallinnonaloja sekä kaikkea poliittista päätöksentekoa, ei vain ympäristöpolitiikkaa.

Keskeinen havainto artikkelissa onkin siirtymä ympäristö- ja luonnonsuojelukeskeisestä puhunnasta ilmastonmuutosvetoiseen retoriikkaan. Ilmastonmuutoksesta ja ilmastopolitiikasta tuli ympäristötematiikkaa käsittelevien täysistuntokeskustelujen hallitsevia käsitteitä 2000-luvulla. Ilmastonmuutoskeskustelu on nykyisin metakeskustelu, jonka alla keskustellaan muista teema-alueen kysymyksistä, kuten ympäristönsuojelusta, luonnon monimuotoisuuden säilyttämisestä ja maapallon lämpenemisen hillitsemisestä.

Eduskunnan täysistuntokeskustelussa käytetyt käsitteet näyttäytyvät sekä muutoksen luojina että heijastajina. Määrällisten ja sisällöllisten muutosten ohella aineistossa oli havaittavissa myös käsitejatkumoita: vanhatkin käsitteet ovat yhä käytössä uusien rinnalla.

Valtio-oppi yliopistollisena tieteenalana Suomessa täyttää tänä vuonna 100 vuotta, ja lehden loppuosa on omistettu tälle merkkipaalulle. Suomen ensimmäinen yleisen valtio-opin professuuri perustettiin vuonna 1921 Helsingin yliopistoon, joskin Turun akatemiassa oli historian ja politiikan oppituoli jo vuonna 1640. Historiallisten prosessien alkupisteiden määrittely onkin tulkinnanvaraista, mutta olipa vuosiluku mikä tahansa, juhlavuosi on aina paikallaan.

Virstanpylväs on yhtäläisesti koko tieteenalan juhla, sisältäen myös kansainvälisen politiikan ja maailmanpolitiikan. Kaikkia politologeja yhdistää se, että olemme päntänneet ainakin joitakin samoja klassikkoja ja jaamme omalaatuisen kiinnostuksen valtaa ja politiikkaa kohtaan.

Juhlaosion aloittaa Erkki Berndtsonin kirjoitus "Sata vuotta suomalaista valtio-oppia", joka luo tiiviin yleiskatsauksen tieteenalamme institutionaaliseen historiaan Suomessa. Tämän 
jälkeen Kari Paakkunaisen teksti "Suomalaisen valtio-opin perustajien sukupolvesta" esittelee valtio-opin varhaisen historian hahmoista K. R. Brotheruksen, Yrjö Ruudun ja Rafael Erichin, jotka edustavat erilaisia käsityksiä politiikasta ja valtio-opista. Vahvana vaikuttajana ja kommentoinnin kohteena Suomessa oli itävaltalaisen Georg Jellinekin (1851-1911) Allgemeine Staatslehre, yleinen valtio-oppi. Pertti Ahonen tarkastelee Suomen yliopistollisen valtio-opin vaihtelevia suhteita hallintoa koskeviin teemoihin kirjoituksessaan "'Hallinto' hankalana teemana Suomen satavuotiaalla valtio-opin tieteenalalla". Hallinnon kehitys yhdestä valtio-opin linjasta omaksi tieteenalakseen, hallintotieteeksi, on esimerkki rajanvedoista tieteenalan sisällä ja tieteenalojen välillä.

Erkki Berndtsonin "Kansainvälistyvä suomalainen valtio-oppi. Valtiotieteellisen yhdistyksen englanninkielinen julkaisutoiminta" valottaa kansainvälistä julkaisutoimintaa suomalaisessa politologiassa. Pohjoismainen yhteistyö oli julkaisutoiminnassa tärkeää 1960- ja 1970-luvuilla. Sen hedelmänä on nykyisin kansainvälinen julkaisu Scandinavian Political Studies. Suomalaisten tutkijoiden englanninkielisten julkaisujen foorumina toimi vuosina 1983-2014 kirjasarja Books from the Finnish Political Science Association. Suomalaisen politiikan tutkimuksen kansainvälistyessä ja politologiyhteisön kasvaessa sarjan alkuperäisen ajatuksen mukaisille kirjoille ei ole enää nähty samanlaista tarvetta. Vuodesta 2020 lähtien kansainvälisille lukijoille on ollut tarjolla Open access -muotoinen kirjasarja Pro et Contra, Books from the Finnish Political Science Association.

Nämä kirjoitukset on julkaistu alun perin Valtiotieteellisen yhdistyksen verkkosivuilla "Valtio-oppi 100 vuotta" -juhlaosiossa. Lämmin kiitos Valtiotieteelliselle yhdistykselle tekstien kokoamisesta ja kirjoittajille uudelleenjulkaisuluvasta! Sivustolle kannattaa mennä lukemaan lisäksi kiinnostavia ja informatiivisia esittelyjä valtio-opista maamme eri yliopistoissa sekä Politiikkalehdenkin vaiheista. Halusimme koota kirjoitukset "samojen kansien väliin", jotta ne löytävät laajan lukijakunnan vielä seuraavanakin valtio-opin pyöreänä syntymäpäivänä. Yhdessä kirjoituksista piirtyy monipuolinen kuva siitä, miten politiikan tutkimusta akateemisena alana on kehitetty muun muassa määrittelemällä sitä suhteessa historiaan, sosiologiaan ja oikeustieteeseen. Teemaosio päättyy Annu Perälän raporttiin lokakuisesta Politiikka-lehden järjestämästä etäjuhlasta, joka kokosi politologeja kuvien ja muistojen ympärille. Koronapandemia on jo pitkään hankaloittanut tapaamisia, joten kokoontumisille on tarvetta vaikka sitten ruutujen ääressä.

Myös Politiikka-lehdellä on eräänlainen merkkivuosi, sillä lehden edeltäjä Valtio ja yhteiskunta -vuosikirja alkoi ilmestyä 60 vuotta sitten. Vuosina 1941-1956 ilmestyneen vuosikirjan perinteen jatkajaksi perustettiin Politiikka vuonna 1959. (Pajala 2009.)

Lehden ensimmäisen numeron pääkirjoituksessa Jan-Magnus Jansson luotaa valtio-opin historiaa ja tuolloista nykytilannetta Suomessa. Hän toteaa, että 1950-luvun puoliväliin saakka tutkimus kohdistui lähinnä kotimaisiin aiheisiin, yhtäältä poliittisiin aatteisiin ja toisaalta valtiollisiin instituutioihin.

1950-luvun puoliväliä Jansson pitää vedenjakajana, jolloin valtio-oppi Suomessa hakeutuu uusille alueille. Hän tulkitsee, että muutos on ollut "radikaalisempaa" kuin esimerkiksi Ruotsissa, mikä osaltaan johtuu hänen mielestään siitä, "ettei Suomen valtio-opissa ole vanhaa kotimaista perinnettä, joka saattaisi jarruttaa painopisteen siirtymistä" (Jansson 1959, 3).

Teemaosion kirjoitukset osoittavat, ettei politologia Suomessa ole ollut yhdenlaista. Vähintään sadan vuoden ikäisestä valtio-opin "kotimaisesta perinteestä" on siis puhuttava monikossa. 
Suomen valtio-oppi sisältää erilaisia tutkimusotteita, joilla tartutaan mitä moninaisimpiin tutkimuskohteisiin. Ja se sisältää myös - toivottavasti yhä enemmän - yhteyksiä niiden välillä. Sekä perinteitä että niiden uudistumista tarvitaan. Jatkukoon tieteenalamme "radikaalinen" liike tulevaisuudessakin ilman turhaa jarruttelua.

\section{LÄHTEET}

Jansson, Jan-Magnus. 1959. Politiikan tutkimus Suomessa. Politiikka 1:1, 1-6.

Pajala, Antti. 2009. Puoli vuosisataa Politiikka-lehteä. Katsaus kansien väliin ja vähän kansiinkin. Politiikka 51:1, 48-58. 